\title{
Understanding the Dynamics and Operations of Civil Society in the 21st Century: A Literature Review
}

\author{
Thomas Prehi Botchway ${ }^{1}$ \\ ${ }^{1}$ Law School, Chongqing University, Shapingba, Chongqing, China \\ Correspondence: Thomas Prehi Botchway, Law School, Chongqing University, Shapingba, Chongqing, China. \\ E-mail: abeikuprehi@yahoo.com; prehionline@gmail.com
}

Received: January 20, 2019

Accepted: February 14, 2019

Online Published: February 28, 2019

doi:10.5539/jpl.v12n1p108

URL: https://doi.org/10.5539/jpl.v12n1p108

\begin{abstract}
This article sets out to review the extant literature on civil society. Indeed the literature on civil society abounds with several views and perspectives, especially on the theoretical debates on the concept. However, in order to avoid the unnecessary entanglement of the unending theoretical debates that have characterized the subject, the article focuses on the activities and operations as well as the usefulness of civil society in the twenty first century. The article consequently tries to identify the literature that discusses the activities of civil society across the globe. It begins by giving a general background to the concept of civil society. This is then followed by discussions on civil society and how it relates to democracy and democratic consolidation and development in different parts of the world with particular emphasis on Africa. It then examines the activities of CSOs in Europe, the Asia-Pacific region (with emphasis on Malaysia). It further examines the changing nature of CSOs in the midst of global crisis by discussing how civil society has operated in challenging times amidst financial crisis, terrorism, etc. It concludes by suggesting some new ways of understanding civil society.
\end{abstract}

Keywords: civil society organizations (CSOs), civil society activities, democracy, democratic consolidation, development

\section{Introduction}

The concept of civil society traces its origins largely to the age of enlightenment in the works of Adam Ferguson who at the time associated it with the development of the economic state and the decline of despotic and corrupt governments in Europe (Ferguson, 1767). Whilst Ferguson's conception blurred the difference between civil society and the state, and leaned toward the market, with the passage of time, other scholars have endeavored to refine his ideas (Masterson, 2007). After years of evolution, CSOs have been described as 'a realm where citizens associate according to their own interests and wishes' (Carothers, 1999, p. 18). A vibrant civil society is therefore the one that is seen to be facilitating and encouraging a vibrant political society. However, in recent times, studies have shown that the concept of civil society has challenges in reframing associations and discovering their actual impact on the governance process (Warren, 1999).

To borrow the words of Diamond (1994), "in this third wave of global democratization, no phenomenon has more vividly captured the imagination of democratic scholars, observers, and activists alike than "civil society" (p. 4). Indeed in contemporary times, the study of civil society has become a prerequisite to understanding the details of democratic change around the world. This is because studies reveal that a vibrant civil society is in many ways crucial for initiating, maintaining, and consolidating a democracy (Diamond, 1994; Botchway, 2018b). However, understanding the role of civil society in the democratic process calls for more intricate constructions and the creation of fine distinctions regarding what civil society is and what democracy ought to be, and this makes such a study a difficult one (Diamond, 1994).

Notwithstanding the numerous publications on the subject of civil society, especially in its theoretical conceptions, this article examines the workings and operations of civil society (not the theoretical arguments). Thus, the caveat must be sent to the reader that the works of certain prominent theorists of civil society such as Adam Ferguson, Adam Smith, David Hume and Adam Seligman, as well as others who fall within what Jensen (2006) refers to as the Scottish Concept are not reviewed. The reason for this approach is to avoid the entanglement of the extreme theory-laden approach to understanding civil society. Thus, though the article may occasionally refer to some theoretical aspects of the concept, the primary focus is on their operations, programs 
and viability, especially in the $21^{\text {st }}$ century. In other words, the article does not intend to, neither can it, resolve the unending and incompatible debates on the definitions and usages of civil society. Rather, it attempts to review the usefulness, activities, and challenges as well as the prospects of CSOs over years.

Indeed, the concept of civil society may be vague since its deployment is often seen in diverse forms and in several dissimilar 'theoretical, practical, and historical contexts' to the extent that modern efforts at deploying the concept in a 'democratic theory are typically more obfuscating than illuminating' (Jensen, 2006, p. 39).

\subsection{Civil Society/Organizations (CSOs): A Diversity of Definitions}

According to Warren (1999), civil society 'refers to varied and multifaceted associational structures that have quite distinct effects on governance, some desirable and some not.' (p.1) Warren further asserts that in some parts of the world, particularly Eastern Europe and the Latin Americas, through the activities of democratic movements, the meaning of civil society has been rejuvenated. Thus, CSOs in these areas are conceived of in a way that is indicative of the laissez-faire resistance that opposed authoritarian states of previous administrations. In addition, in modern, pluralistic, and complex societies all over the world, democracy as has been argued by Warren (1999), 'depends upon a number of associational contributions, including those that develop the capacities of citizens, enable public judgments, and underwrite democratic institutions such as representation' (pp. 1-2). Thus, CSOs are seen to be playing vital roles in both the democratization and consolidation processes.

The notion of civil society as employed in Political Science in modern times trace its roots to the works of the Italian Marxist Antonio Gramsci (1971) and the French aristocrat Alexis de Tocqueville (1820) (Bernhard, Tzelgov, Jung, Coppedge, \& Lindberg, 2015). While the Gramscians perceive civil society as 'a realm of contestation, where organized social actors challenge the power of the state and other social forces', the Tocquevilleans perceive civil society as 'the very integument of democracy' (Bernhard, et. al., 2015, p. 3). Thus, one can find the roots of civil society deeply planted in both the liberal and Marxist traditions of European political thought. For instance, de Tocqueville's emphasis on the significance of voluntary associations in encouraging independent citizenry, as well as Gramsci's stress on the role of social institutions in both reinforcing and demanding accountability in the exercise of state power clearly attests to the relevance of civil society. The point must be reiterated that de Tocqueville does not support mob rule. His thought instead called for effective engagement by the organized citizenry which promote a more egalitarian, people-oriented, mass-based form of governance.

John Locke and Thomas Hobbes are among the many prominent philosophers who opine that civil society and the state are distinct entities. These scholars are of the view that though the two are not identical, the latter is accountable to the former, and as such should be identified with it (Masterson, 2007). In other words, the state cannot exist in any meaningful way without civil society and likewise without the state CSOs can never find relevance.

The rapid changes in society and the changing roles that various groups play have also meant adopting new ways of defining civil society. Consequently, new designations about civil society have sought to reject several groups from been associated with it (Jensen, 2006; Masterson, 2007). For proponents of liberal egalitarianism, civil society ideally is 'a realm in which citizens pursue their comprehensive ends and develop the principles, practices, and virtues conducive to democratic government' (Jensen, 2006, p. 51). As opposed to classical liberals who regard a minimally-regulated economic market as the core for an effective civil society, some liberal egalitarians postulate that the control and influencing powers of a sturdy central government is a necessity for maintaining the democratic nature of a political culture (Jensen, 2006). Thus, employing diverse theoretical approaches in analyzing the social and political models of civil society will eventually produce different understandings of what CSOs are and are not, and what they ought to do or refrain from doing.

\subsection{The Robustness of Civil Society}

Civil society robustness refers to its ability to maintain its independence from the control of the state and the ability of the citizenry to actively pursue their shared goals without unnecessary state interference (Bernhard et al., 2015).

In recent times, the study of CSOs has been taken to a different level: work has been done to quantify the relative effectiveness and robustness of CSOs across the globe through the 'Core Civil Society Index (CCSI)' (Bernhard et.al, 2015, p.10). Using what they refer to as the 'Varieties of Democracy battery on civil society', and adopting a 'time-series cross-sectional analysis' involving two thousand hundred and ninety-nine 'country-year observations between 1989 and 2012', Bernhard et. al. (2015, p.2) examined the 'measure' of the robustness of civil society. Their work postulates 'the CCSI's utility by examining the question of whether postcommunist civil 
society is "weak" compared to other regions' (p.2). The study finds that 'there is no evidence to substantiate that postcommunist civil society is less robust than civil society in other major world regions' (p.2), and that 'the development of civil society in the postcommunist world is not particularly different from that of other regions' (Bernhard et al., 2015, p.32). The study also argues that 'the existence of civil society is a necessary but not sufficient condition for democracy' and that 'civil society is compatible with both authoritarian and democratic political systems' (p.8). They consequently posit that thinking of civil society by reflecting on its capacity to operate and effectively engage the citizens without the state putting any impediments in its way is a sure way of measuring its strength.

The global expansion of democracy in recent times has also lead to the concurrent growth and expansion of civil society and their related activities in contemporary times. However, the viability and potency of civil society have over the years varied geographically and that regions with a history of sustained development, competitive politics, and political pluralism such as North America and Western Europe have the strongest civil societies. On the contrary, regions with long histories of harsh dictatorship and lagging development such as South, East and Southeast Asia, as well as the Middle East and Africa, etc. have weaker civil societies. The point here is that 'historical events have important ramifications for the development of civil society' around the world (Bernhard et.al, 2015, p.14)

As several studies have shown, a vibrant and independent civil society is a sturdy prerequisite for the continued existence of democracy across the globe (Botchway, 2018b; Bernhard et.al, 2015; Diamond, 1997; Gyimah-Boadi, 1996; Bratton, 1994).

\section{Civil Society, Democracy and Democratic Consolidation}

\subsection{The Democracy-Support Functions of CSOs}

Diamond (1997) has argued that democracy can be promoted by civil society in 'two generic ways.' These include activities of CSOs that assist in generating 'a transition from authoritarian rule to (at least) electoral democracy, and by deepening and consolidating democracy once it is established' (p.25). He also identifies thirteen functions of CSOs which have come to be known as the democracy support-functions of CSOs. Notable among these functions is the fact that civil society serves as 'the basis for the limitation of state power, hence for the control of the state by society, and hence for democratic political institutions as the most effective means of exercising that control' (Diamond, 1997, p. 36).

Diamond concludes the functions by arguing that by 'enhancing the accountability, responsiveness, inclusiveness, effectiveness and hence legitimacy of the political system, a vigorous civil society gives citizens respect for the state and positive engagement with it' (p. 55). This according to him eventually supports in building an effective government structure that enjoys willful compliance from the citizenry.

Notwithstanding the seemingly positive publications about civil society, there still exist others that identify civil society activists as avenues that can be used by some illiberal groups to oust existing democracies (Berman, 1997; Riley, 2010; Lewis, 2013). The point must however be noted that having more open states with efficient CSOs that represents the diversity of the society have a higher proclivity in reducing state-opposed groups and mob-like CSOs (Bernhard et.al, 2015).

\subsection{Civil Society and Democratic Consolidation}

When democratic practices become ingrained in the affairs of the state, and deeply legitimate among the citizenry to the extent that its breakdown is quite unforeseeable, then consolidation is said to have occurred. This implies changes both at the individual and institutional levels such that these changes reduce uncertainties and also normalize democratic practices (Botchway, 2018a). In order to achieve this normalization, there is the need for expanding the citizen's access, as well as developing 'democratic citizenship and culture, broadening of leadership recruitment and training', etc. There is also the need for ensuring 'political institutionalization' (Diamond, 1994, p. 15).

Over the years, there has been the belief that civil society serves as an effective tool for the generation of political approval and as such it has become the basis for asserting the legitimacy of state's authority (Botchway, 2018b). Consequently, elites may not be able to exercise authority without the consent and approval of the masses: 'for as long as civic actors grant consent, civil society exists in a complementary relationship to the state' (Bratton, 1994, p.9). Accordingly, without civil society, elites lack the legitimacy to employ state power. Thus, without a functional civic community, there would not be any effective and receptive governance system. This forms the basis for what Putnam (1993) has described as 'the seeds for a theory of democratic governance' (p. 87). Concurrently, Walzer (1991) opines that 'the quality of our political and economic activity and our national 
culture is intimately connected to the strength and vitality of associations' (p. 298). Other scholars advise that it would be in the interest of political leaders who cherish their continuing legitimacy to uphold and encourage the democratic practices and effectiveness of civil society, irrespective of the higher societal demands this may bring (Cohen \& Arato, 1993).

Some scholars have identified civil society as associations and subsequently divided their functions into several categories. For instance, Warren (2001) identifies three main types of tasks that associations engage in. According to him, one of the critical elements for ensuring the development of the individuals' sense of usefulness in society is through effective participation in associations. This participation also provides the individual with relevant political information as well as skills that enhances their overall participation in the state. In addition, associations form the basis for enhancing the general discussion of relevant societal issues such as effective representation and giving relevant feedback to the society. Additionally, associations, through their effective interactions with the institutions of state, also have enormous effects on the administrative, legislative, and the policy making processes of the state (Warren, 2001; Fung, 2003). In similar vein, some scholars opine that beyond representing interests, associations also help in facilitating civic deliberations (Cohen and Arato, 1994; Habermas, 1996). Some scholars are however of the opinion that due to the very nature of their activities, many associations that usually offer effective political resistance may not be able to promote tolerance, trust, and reciprocity as well as the respect for the rule of law (Fung, 2003).

It has also been the contention of others that though political decisions may be vulnerable to financial manipulations and other influences, civil society constitutes a major sphere for the promotion of deliberative democracy and consequently enhances effective communication in the given society (Fung, 2003; Beck, 1999). To such scholars, it is through the platforms created by CSOs that salient issues of the society such as racial prejudice, gender equality, environmental justice, as well as degradation, and others are usually spearheaded and subsequently passed on to political and economic fields (Fung, 2003).

Although, in Habermas' (1996) view, CSOs and the general public do not usually have the clout to solve the problems they may identify in society, they can nevertheless initiate the process of setting the agenda for effective and proper deliberations by drawing the state's attention to the identified problems. Consequently, studies have shown that civil society have over the years played a relatively direct role in enhancing the state's role of formulating public policy, the provision of services, and regulating harmonious relations (Hirst, 1994; Cohen \& Rogers, 1995; Najam, 1999; Fung \& Wright, 2003). However, liberal democratic theorists see 'a strong state and a strong civil society as separate from, yet essential complements to, one another.' Thus, for this group of scholars, 'civil society exists only in its relationship to the state' and that 'it is not envisaged as a potentially democratic sphere in its own right through which alternative visions of democracy might be pursued' (Mercer, 2002, p. 7).

\section{Civil Society, Democracy, and Development in Africa}

Contemporary studies on civil society in Africa have witnessed scholars attempting to construct the origins of CSOs on the continent. Evidence shows that the works of CSOs in Africa has undergone substantial changes within the last two decades. This is seen in the consolidation of the good governance agenda and strengthening of institutional constellation across the continent (Mercer \& Green, 2013; Gyimah-Boadi, 1996).

Starting from the early 1990s, debates about democratization in Africa have regularly been marked by 'a hegemonic idea of civil society' (Whitfield, 2002, p.4). However, prior to this period, civil society in Africa was conceived as a 'theoretical construct' meant for understanding an 'observed phenomena' rather than been viewed as 'a thing to be studied' (Whitfield, 2002, p.4). Consequently, the recent interest in the subject has focused more on the concept as an 'object of research and less an analytical category' (Whitfield, 2002, p.4). Thus, contemporary attempts at divorcing civil society as an idea from 'the agency of the groups it purports to describe' is no longer tenable. Civil society in Africa has consequently become the decisive arena for improving citizen control of the community (Whitfield, 2002).

There is the idea that without the existence of vibrant CSOs on the African continent, as far as the pursuit of essential changes in the administrative system of the state is concerned, scanty progress may be made (Cox, 1999). However, some scholars have opined that "the application of "civil society" in the "South" (particularly Africa) 'is necessarily problematic because it forms part of a universal language, emanating from the West, which tries to describe a universe that is inherently particular' (Kaviraj, 2001 cited in Whitfield, 2002, p.9).

Moreover, as Whitfield (2002) has indicated, aside introducing 'a language in which the question of how to form the social basis for a new political authority can be formulated and debated' in African politics, 'civil society as idea' also contains 'the hegemonic influence of Western thought' which Western governments intend Africans to 
adopt. As a result, this feature of 'civil society as idea' explicates the difficulty in attempts at clarifying what civil society really is and what it really does and seeks to achieve in Africa (p.9). Eventually, for some scholars, there is the purported perception of civil society as 'a superior way of organizing state-society relationships' and this by implication means 'civil society ought to exist' for the reason that it is presumed to be the 'only viable or conceivable foundation for democracy....Apparently, like democracy, one has to have civil society to belong to the modern world order' (Hutchful, 1995 cited in Whitfield, 2002, p.10). It is therefore argued that having a well organized and efficient group is a prerequisite for effectively participating in that 'counter-hegemonic' agenda aimed at challenging the excesses of a domineering state (Whitfield, 2002, p.14; Kröger, 2018a).

Accordingly, by enhancing the potentials of social groups and associations, the citizenry are been effectively equipped with the needed skills and knowledge that would be useful for not just challenging the existing institutional structure, but also for effectively regulating the relations between them. As Whitefield's (2002) study reveals, through the building of the organizational capabilities, some groups on the continent have been able to enhance their relations with the post-colonial African state. Thus, through the development of efficient and capable CSOs across the continent, a new definition of state-civil society relationship has been pursued. Moreover, though the conventional view of civil society usually limits the term to particular category of non-state institutions that are preoccupied with certain organizational activities intended to improve accountability, transparency and democratic credentials of a country, as Whitefield (2002) asserts 'civil society as idea provides a means to an end' and that this 'idea has historically been a discursive tool employed to articulate visions of a better society' (p.14).

Over the years, African CSOs, in many cases have not been able to manage the task of been effective tools for deepening democratic practices on the continent; they struggled to adapt from their past role as activists against governments (Masterson, 2007). Besides, the many internal problems (identity crisis, social structure, dual allegiance, etc.) of most post-independence African countries creates several difficulties for conceptualizing civil society in a way that may be in tune with the Western pattern. Thus, for liberal-democratic-oriented donor agencies operating in Africa, civil society is not just a means to an end, but also an end in itself. This implies that instead of directly attempting to influence African governments to implement Western-oriented reforms designed to engineer economic liberalization that may be seen as favoring Western nations, CSOs can perform this task without much suspicions and difficulties. In addition, CSOs are themselves avenues for improving the wellbeing of the society. Civil society is therefore perceived as the new answer for the promotion of a strong economy while at the same time enhancing democratic governance for African countries (Whitfield, 2002; Mercer \& Green, 2013).

Consequently, in their study of CSOs in some African countries, Mercer and Green (2013) have attempted to address the question 'what is the work that gets done' by civil society organizations given the donor resources made available to them?' They contend that 'a more open-ended approach to civil society sector work will produce different insights from approaches that ask "does civil society work?" or, "how does civil society work?"' In their view, whereas the first question 'tends to be asked from a normative standpoint' and is usually related to evaluating CSOs input into 'progressive politics', the latter 'has recently been addressed in analyses framed by a governmentality approach in which the disciplinary effects of responsibilisation account for civil society action' (Mercer \& Green, 2013, p. 107). They have accordingly asserted that by making different queries of what CSOs do day by day, it is possible to notice that 'civil society policy template' offers substantial means for achieving anticipated results.

In their study conducted in two of Tanzania's pastoral areas, Mercer and Green (2013) found that there have been scanty specialization between CSOs in these districts, and that comparatively, several local organizations compete among themselves with the purpose of wining the available limited funding to undertake basically the same activities in both districts- activities related to giving support to people with HIV/AIDS and 'most vulnerable children' (MVC) (p.109). Their work also shows that there is an 'over-supply of CSOs' in these districts and that instead of viewing CSOs as 'permanent organisations' in these areas, 'it is more accurate to think of them as dormant organisations that come to life periodically when they win donor funds for a specific activity or project' (pp. 109-110). Their findings have also indicated that efforts by home-grown CSOs are usually 'generated by a contracting model' and that it is through these models that these 'CSOs compete for donor funding to deliver small discrete projects in areas' that are deemed as 'civil society activity' (Mercer \& Green, 2013, p. 110). They argue that this situation leads to the creation of "project enclaves" that usually "serve to undermine the state through "capacity de-building", the exit of qualified staff to NGOs and the creation of overpaid parallel bureaucracies' (p.110).

They have subsequently indicated that there exists a complex transnational contracting chain of CSOs which 
have been created by financing from global donors and it usually targets the formation of CSOs patterned in a manner where the link between indigenous CSOs and donors is 'mediated by several sub-donors and sub-recipients.' This situation in their view has created an environment for CSOs to 'become local project managers' who facilitate development solutions by 'bringing together donor money and the relevant expertise in order to manage particular donor-designed interventions' (p.110).

Due to the nature of CSO works in the Tanzanian region-the 'competitive contracting model of short-term CSO engagement', people in this area have described what they do as 'volunteering.' This according to Mercer and Green (2013) challenges the common notion that posits that the "desire to milk the development industry for personal gain' is what motivates indigenes to perform 'development work' on the African continent. They however propose that voluntary work in the CSOs is also characterized by a 'politics of virtue' in which CSOs are 'aligned with the virtuous' labor aimed at 'helping the rural poor, with two key effects.' Firstly, they opine that 'the self-designation of all civil society workers as volunteers masks the highly divergent costs and benefits of volunteering between, for example, the CSO leader and the village volunteer' (p. 111). Secondly, they have pointed out that as compared to 'the perceived failures of government as an agent of local development', CSOs are 'constructed as virtuous' and that they have become 'the most effective agent' that undertakes particular development interventions in the rural communities. Consequently, CSOs dependence on the local administration's 'technical experience and expertise in order to deliver development contracts is rendered invisible' (p.111).

In concluding their work, Mercer and Green (2013) have reiterated the fact that current development discourse constructs on the continent gives an indication of a changing trend in the civil society sector. They argue that CSOs have become partners of the state and donors. However, contrasted with previous years during which CSOs were 'to be supported' as alternative service providers, they are currently 'cast in the role of rendering public provision more effective through policy engagement, advocacy and ensuring accountability' (p. 113). They have further indicated that rural CSOs in Tanzania have developed during the most recent decades due to the availability of donor funding which aims at establishing the 'lower tiers of the national vertical civil society template', thereby making CSOs 'the projects of bigger projects' and 'a contractor in the delivery of intangibles' (p. 113).

In consequence, CSOs have been major stakeholders in helping in the formulation and implementation of various programs aimed at the eradication of poverty, promoting good governance, and consolidating democracies in Africa (Mercer, 2003; Mercer \& Green, 2013; Botchway, 2018b). For instance, CSOs in the late 1990s were key instruments in producing the National Poverty Eradication Strategy (NPES) which was an important document that outlines Tanzania's plans that aimed at reducing poverty in the country (Mercer, 2003). Notwithstanding this achievement, Mercer (2003) has also indicated that in Tanzania there is a clear evidence to show that only a tiny group of elite professional groups/CSOs, and the collaborating global NGOs, have enjoyed much benefits from the seemingly partnership created by international donors and CSOs. This situation, Mercer (2003) opines, 'highlights the contradiction between the rhetoric of partnership and the limited ability of civil society to represent a broader societal view to policy makers' and that 'aid relations as currently constituted are not characterised by a genuine partnership in which all development partners have equal power to influence Tanzania's macroeconomic, social and political trajectory' (p. 748).

CSOs in Africa channel and process the concerns and demands of different interest groupings to the state. By so doing, they highlight the need for a valuable and efficient state that guarantees accountability and transparency as well as legitimacy in the governance process. It consequently strengthens the ability of the state to maintain good governance in the long run (Mercer, 2002).

\section{CSOs in Europe: a Call to Duty or an Europeanization Agenda?}

A recent study by Nilsen, Strømsnes and Schmidt (2018) analyzes the efforts of 101 different organizations that came together under the umbrella of climate change mitigation just before the 2013 Norwegian parliamentary elections. The aim of the group was 'to make climate change mitigation the most important issue in the election campaign' (p. 20). According to their study, the alliance - Climate Election 2013 (CE2013) 'agreed on six political demands' that related to climate improvement (p. 20).

The study aimed at categorizing the 101 organizations and discussing their identities as well as objectives in relation with the six 'demands' they proposed. Their analysis eventually exhibits that while 'a broad variety of organizations joined the campaign, their commitment was rather weak' and that only a 'few of the organizations justify their involvement in CE2013 by all six political demands.' This they argue demonstrates that 'climate change mitigation is a valence issue' (that is, the different CSOs have 'agreement with regards to their "goals", 
nevertheless regularly disagreed 'when it comes to the question of how best to achieve the goals') (Nilsen, Strømsnes, \& Schmidt, 2018, p.20).

The primary objective of their research was to explore and establish the extent of commitment of the groups that came together to form CE2013, and to establish 'whether the campaign' inferred 'an idea of political strength and influence for the organizations on the climate issue.' They also argue that through the CE2013 campaign, the various CSOs envisioned joining forces to push for the climate mitigation 'might bolster their organizational identity and increase their legitimacy' (Nilsen, Strømsnes, \& Schmidt, 2018, p.21). The study consequently concludes that the formation of the CE2013 and its activities and campaign in the 2013 Norwegian parliamentary elections exemplifies one way CSOs can pursue political strength by using 'the appeal and attractiveness of more basic political concerns', ideas and the authority and the 'credibility it incurs on those invoking them' than in 'terms of fighting for specific political positions and decisions and trying to rationally convince others about their superiority’ (Nilsen, Strømsnes, \& Schmidt, 2018, pp. 37-38).

According to Chaney (2016), existing CSOs studies have over the years generally failed to thoroughly study how 'contextual factors shape women's representation in the civil sphere' while at the same time political scientists also largely focus more on lawmaking and its related activities. It is in this regard that his paper attempts to respond to the 'resultant knowledge-gap.' He asserts that 'civil society and political science research have been slow to recognize the implications of revised governance practices for the substantive representation of women (SRW).' He subsequently examines the previously 'underexplored role of civil society as a political space integral' to SRW (p. 198).

By adopting a grounded theory, Chaney (2016) proposes a systematic analytical model which depicts how the concerns of women can be pursued in the policy-making process. His grounded theory also depicts 'politics as a contingent process whereby the motives of' CSOs 'are translated into action repertoires shaped by three non-discrete spheres' namely political, socioeconomic, and organizational spheres. He argues that CSOs are appropriate tools to advance existing perspectives about the representation of women for the reason that they are 'positioned at key social and political' junctures (Chaney, 2016, p. 199).

Commenting on the role of CSOs within the European Union (EU), Kröger (2018a) building on Putnam's (1993) and Habermas' (2001) arguments, have asserted that 'as a political community in the making, the EU requires a shared identity, trust in the reciprocity of the rule-abiding behaviour of others, and mutual solidarity' (p. 43). She postulates that though research findings regarding the fulfillment of these 'high expectations are rather sobering', civil society has the capacity to ensure that this required trust in the EU is guaranteed by 'creating a shared public sphere, and by functioning as transmission belts that bring the interests and values of citizens to the EU' (p. 43).

Applying the concept of 'usage' as developed by Woll and Jacqot (2010), Kröger (2018a) differentiates between two kinds of 'usages of the EU by CSOs' namely 'strategic usage', which according to her 'occurs when actors pursue a specific goal that is related to the immediate interests of the organization they represent', example 'when CSOs lobby to try and influence legislation and/or when they seek EU funding' (p. 44). The second usage she terms 'principled' since here 'CSOs' engagement with the EU goes beyond their own immediate material interests, in that they are interested in supranational democracy' (p. 44).

Kröger (2018a) uses three groups of CSOs as the basis for her analysis with the reason been ensuring variety. The groups included agricultural-related CSOs ('members'), environmental-related CSOs ('cause') and the 'anti-poverty' CSOs ('weak interests'). Whereas she describes the member-based CSOs as 'typically organize and mobilize professional interests, often with (re)distributive effects that directly concern the members', she asserts that the "cause" groups represent a cause which is not capable of representing itself' and may include 'the environment, animals or future generations' (p. 45). Thus, while 'members' CSOs have 'strong personal' incentives 'for their group to lobby on their behalf' to directly influence economic well-being, affiliates of the 'cause' CSOs 'are not immediately concerned by the results of the organizations' activities' (Kröger, 2018a, p. 45).

The third group-'weak interests' groups, according to Kröger (2018a) includes 'human constituencies', for instance children, the underprivileged, the destitute or those who are generally underrepresented in electoral representation and also 'do not enjoy the sorts of capital necessary to defend their own interests' (p. 46).

Kröger's (2018a) study finds that, CSO actors that are engaged in the agricultural sector 'are highly engaged in strategic usages of the EU' and that this echoes the legal as well as the material inducement offered by the Common Agricultural Policy (CAP) for farmers within the EU. Thus, the existence of the single market, common regulation, and the CAP, as well as the 'the financial security that comes with it' is very strategic to 
agriculturally-related CSOs and their operations within Europe. However, these same CSO actors see 'the pursuit of the lowest common denominator policies and being governed from far away in Brussels' as a disadvantage ( $p$. 49). With regards to the environmental CSOs, Kröger (2018a) finds that these players are vigorous in very "integrated" fields and thus symbolizes a concern that normally 'transcends national borders' (p. 49).

Kröger (2018a) finds that 'anti-poverty' CSO players, as compared to the other groups, regard their lobbying conduct as been less significant at the EU. This, her study indicates, reflects the lower degree of Europeanization' of anti-poverty CSOs (p. 54). Though issues involving the diversity of concerns within the EU are significant reasons for this somewhat low EU reputation (Kröger, 2018b), the limitation by time and inadequate resources, according to Kröger (2018a), are the main reasons.

Kröger's (2018a) work also postulates that as far as most CSOs in Europe are concerned, lobbying is 'deemed more important than contributing to democracy', though 'EU democracy also matters' for CSO actors (p. 55). Though Kröger asserts that ' $\mathrm{h}] \mathrm{low}$ one interprets the data will have much to do with epistemological and ontological choices and preferences' (p. 55), the scenario actually points to the age-long argument that CSOs exist to pursue their own interest (Morley, 1884).

Kröger (2018a) concludes that linking a 'strong normative role to CSOs in democracy promotion has probably always been more of an academic discourse than something the majority of CSOs would have claimed, even though again this discussion ultimately boils down to different concepts of democracy' (p. 55).

\section{CSOs in the Asia-Pacific}

In an attempt to analyze the development and influence of CSOs in Malaysia, especially under competitive authoritarian rule, Giersdorf and Croissant (2011) have raised three key questions. They first attempt to find out the role that CSOs play in a 'competitive authoritarian' system. Secondly, they pose the question to determine whether CSOs can successfully challenge authoritarianism. Finally, they try to know whether 'the existence of a civil society' strengthens 'the stability of authoritarian order' (p. 2).

So as to offer relevant responses to these queries, their study identifies institutional legacies which are of 'great influence on the structures and functions' of CSOs in Malaysia. This they achieve by adopting the 'historical institutionalism' model in undertaking analysis. In the end, their study indicates that in Malaysia, the role and makeup of CSOs have altered considerably during the past fifty years and that as in other places across the globe, CSOs have emerged as 'challengers to the autocratic elites' in Malaysia (p. 1). They however find that 'the institutional framework of competitive authoritarianism' that exists in Malaysia places heavy restrictions on 'civic engagement and the establishment of civic associations' (Giersdorf \& Croissant, 2011, p. 1).

Their study nevertheless indicates that 'the use of coercion and co-optation is restricted due to the regime's competitive character' and this produces 'a structurally, functionally and operatively limited civil society' (Giersdorf \& Croissant, 2011, p. 1). They also find that CSOs through their cooperation with opposition groups may become very useful, especially in situations where they team up with such groups in mobilizing electoral votes (p. 3). For instance, the seemingly electoral successes of the opposition parties in the 1999 and 2008 elections in Malaysia, they argue, would have been impossible if not for the closer ties CSOs forged with the opposition.

Moreover, the study also gives an indication that having CSOs does not automatically put repressive and authoritarian administrations in jeopardy since competitive authoritarian regimes may have the ability to co-opt oppositional forces (including CSOs) 'through democratic institutions' and eventually 'channel public protest' through these groups, thereby contributing 'to the persistence' of such regimes (Giersdorf \& Croissant, 2011, p. 4).

Giersdorf and Croissant (2011) further assert that 'by giving voice to disadvantaged and marginalized groups in the media arena, or by supporting opposition parties in the electoral arena, civic actors' in Malaysia have been challenging the 'vested powers' monopoly of opinion and representation.' However, these same CSOs, if effectively co-opted by the authoritarian regime may convey considerable details thereby serving as major link for transmitting information to 'the autocratic incumbents' (p. 5). Besides, CSOs could also serve as vital tools that could enhance the grip of authoritarian administration particularly when such groups have the capacity to manage constituents as "“vote-banks" for them', and in so doing may actually strengthen authoritarianism (p. 5).

Giersdorf and Croissant (2011) have consequently argued that the system of government created in Malaysia at independence in 1957 'acted as a guardian of Malay interests and identity' and also 'nurtured the economic interests of Malay peasants' (p. 7). As a result of this, prior to the public unrest of the late 1960s, this 'political formula' was very much cherished to the extent that civic organizations and religious associations as well as 
Malay cultural groups were reluctant in the development of CSOs that could challenge the existing political order (p. 7). Hence, even when most CSOs existed, one could not classify them as self-governing since several of them were either initiated by the existing government or had very close ties with the state. The ethnic Indians and Chinese on the other hand were much more interested in engaging in 'civic activism' at this same time the Malays were complacent for the reason that 'only central elements of the Malay identity were protected by the new constitution' (Giersdorf \& Croissant, 2011, p. 7). Thus in order to protect their cultural interest, these Indo-Chinese Malaysians organized themselves into huge and formidable associations and pursued their cultural interests.

After the riots and restructuring of power structures in Malaysia, civil society once again took to the path of gradual maturity both quantitatively and qualitatively in the 1970s. However, with the introduction of new policies such as the National Economic Policy (NEP) which encouraged 'the emergence of a new Malay middle class which was entirely state-dependent', and which laid emphasis on 'communal identity and Malay dominance within the Malaysian society' to the detriment of Chinese and Indian communities, coupled with the 'non-intended effect of strengthening the Malay belief that Malaysia is the land of the Malays... while the non-Malays were considered to be sojourners', discontentment was unavoidable (Giersdorf \& Croissant, 2011, p. 8).

Accordingly, though the real form of Malaysia's 'institutional configurations related to the development of civil society' has been altered with the passing years, the immense 'strategic purpose' and continued existence of the authoritarian government 'remained constant' (Giersdorf \& Croissant, 2011, p. 10). Giersdorf and Croissant (2011) therefore posit that 'the growth and diversification of civil society cannot be taken as a guarantee for the ability of its components to become agents of democratic change' (p. 10), and that elite strategies such as 'institutional containment', 'associational manipulation' and 'the selective dispensation of punishments and favors' as identified by Schedler (2009), has the propensity to effectively co-opt groups of 'social interests and work towards the disempowerment' of the key players. They have also asserted that 'the existence of a limited but divided civil society may actually strengthen the stability of the authoritarian polity by contributing to its legitimization....' (Giersdorf \& Croissant, 2011, p. 10)

In Malaysia, it is reported that CSOs, especially Muslim NGOs and organizations, offer meaning assistance to the government, especially within the media. Consequently, with regards to issues on the enforcement of Islamic laws, these 'conservative Islamic groups have positioned themselves as dominant forces in the public debate and violate the basic principle of freedom of expression.' They as a result 'weaken the role of civil society as a challenger in the media arena and limit the function to communicate alternative opinions or interests' (Giersdorf \& Croissant, 2011, p. 13).

\section{CSOs in the Midst of Global Crisis}

In recent times, three major crises have dominated the globalized political landscape: 'trans-national terrorism, financial crisis, and climate change.' According to Clark (2011) these crises have collectively hurt CSOs and contracted its 'political space' since the 'rights of association and to state information' which are the fundamentals of civil commitment have gradually 'been eroded in the name of "state security" (p. 241).

Consequently, some scholars have attempted to examine how these crises have moulded and affected the contours and operations of modern days' CSOs (Simiti, 2017; Clark, 2011). For these scholars, these crises have the tendency to forge divisions among CSOs, and also weaken their political influence and effectiveness. The crises, they argue, also have the propensity to reduce citizen support for many CSOs and lead the public to 'see states (not CSOs) as "the saviour", while at the same time exacerbating the pressure between civil society and the state (Clark, 2011, p. 242).

Clark (2011) has argued that CSOs tend to be 'more effective and united during the identification and formation' stages of a crisis. In other words, CSOs are more effective 'when its task is getting the issue onto the agenda' (p. 242). However, they tend to fragment during the latter part of the crisis (resolution stage). The reason for this difference according to Clark (2011) lies in a number of issues. Firstly, at the onset of a crisis, there are varieties of 'tactics for alerting public concern on a topic', but the strategy essential for persuading elected officials 'to change policy tend to be at odds with those for awakening interest within the broad public.' Moreover, 'mediagrabbing and colourful tactics of mass demonstrations and direct action tend to turn off policy-makers' (Clark, 2011, p. 242).

Studies have shown that global financial crisis usually leads to substantial falls in civic contributions for both local and international CSO projects (Clark, 2011; Simiti, 2017). This in turn leads to an augmented dependence on government financial support which further shrinks the autonomy of CSOs thereby making them vulnerable 
to the dictates and pressures of governments.

In terms of terrorists' related activities, it has been said that the key destructive 'indirect impact of the "war on terror" on civil society stems from the heightened governmental scrutiny and restrictions CSOs are subjected to' (Clark, 2011, p. 248). Thus, subsequent to the September 11 assail on the US, representatives from the major developed states held meetings with the aim of putting forth stringent measures to battle terrorist groups via identification and then terminating their sources of finance. This had ramifications for most CSOs, particularly those in third world countries, and organizations related to Muslim countries and funding charitable courses in Muslim communities in particular. Thus, with its new widened mandate, the Financial Action Task Force on Money-Laundering and Counter-Terrorism (FATF), especially with the introduction of 'Special Recommendation 8' (SR8), has impacted the financial viability of CSOs.

Clark (2011) argues that the attempt aimed at tracking the sources of finance for terrorists should not undermine the good course of CSOs. To him, the stigmatization of aid organizations, which results from the war on terror (WOT), have caused 'many people of goodwill throughout the world' to 'become alienated' (p. 250), therefore affecting CSOs across the globe. Moreover, as part of the WOT, several laws have been introduced to 'restrict the legal space for civil society' (Clark, 2011, p. 251).

Civil society has over the years been the most influential entity as far as the environment is concerned. They, until recently, have been the major groups that have dominated the media and shaped public opinion, and provided leadership in policy-making on the environment (Giersdorf \& Croissant, 2011; Clark, 2011). Clark's (2011) study however gives an indication of the changing terrains for three reasons. According to him, governments in the developed nations are in recent times keen to seize issue leadership. In addition, there is a 'new breed of climate-sceptic' CSOs that are mainly made of 'right-wing politicians, business interests, and conspiracy theorists which has muddied the public debate.' Finally, he argues that CSOs 'have often been linked to exaggerated claims and polarized positions, from which policy-makers and climate scientists are increasingly keen to distance themselves' (p. 251).

Clark consequently concludes his work by asserting that in order for CSOs to 'remain relevant in today's policy arena'; they ought to exhibit their capacity in making meaningful contribution to responding to 'today's major crises, rather than just putting issues on the public agenda.' Thus, CSOs are expected to 'point to solutions' and 'not just identify problems' (Clark, 2011, p. 257). They must 'pinpoint most compellingly the fairest and most effective solutions to those problems' and showcase that they 'can play a vital role in ensuring that governments at all levels do what they must to achieve those solutions' (Clark, 2011, p. 258).

Simiti (2017) investigates the impact of the economic crisis on Greek civil society. Using Greek CSOs as the basis, she outlines two main issues - the 'density of civil society', which she asserts could be a 'misleading indicator of its strength if abstracted from the broader economic context', and that 'the economy is not merely an external force, enabling or hindering the development of associational activity' (Simiti, 2017, p. 354). She asserts that Greece's political advances during the years 2015 and 2016 coupled with the victory of the left-wing party, have led to weakness of collective mobilization in the Greek civil society even though solidarity structures have been able to mobilize at some point to offer various forms of support to the society, particularly the vulnerable (p. 367).

Simiti (2017) has argued that the Greek civil society has been affected by the economic crisis of the country. She subsequently identifies elements such as the rise in social needs and awareness of social problems, as well as "the diffusion of feelings of solidarity", and 'citizens' modified economic and psychological needs' coupled with the 'radicalization of civil associations and the correspondingly broader appeal of direct social action and prefigurative politics' as the key factors that have impacted on the Greek civil society (p. 367).

Simiti's study concludes that despite the rise in civic associational life in the country, the speedy 'deterioration of the quality of citizenship' during the economic crisis has damaged the potency of civil society Greece. It has consequently been asserted that instead of depicting a distinct conclusion about the present state of Greek CSOs, one ought to do the assessment of the impact of the crisis on different aspects of civil society (Simiti, 2017). This stems from the fact that notwithstanding the crisis corrosion of the equal representation of social groups and transformation of the nature of civic engagement, civil society has also become denser. It is therefore opined that economic crisis are 'not merely an external force enabling or hindering the development of associational activity', but they also leave 'an imprint on civil society's infrastructure as well as on the nature and patterns of civic engagement and participation' (Simiti, 2017, p. 368). Thus, though CSOs may not be cohesive since tensions are inherent in their attempt to shape policies, it still has a higher propensity of holding tensions that reflect shared experiences as well as perceptions of risk and reward (Martin \& Andrée, 2017). 


\section{Conclusions}

What civil society really is depends on the context in which the concept is been applied. Thus, civil society can be the body, the group, the entity or institution that works to improve the governance process but is not the government; the space that serves for the actualization of the collective good of the society without necessarily aiming to gain material profit; the think tank that exists for the civic education of the citizens, independent of the state; and that professional entity which exists not just to promote and seek the interest of members, but also to ensure equity and fairness in society by bridging gaps of identity and inspiring hope for the common good.

Moreover, since the definition of civil society distinguishes between civil and political society, whenever civil organizations partake in the electoral practice with the intension of capturing political power, there ought to be a cessation from being part of the entity referred to as civil society. Under such circumstances, the classification as political society becomes more appropriate for describing this group. Thus, there is the need to adopt a 'particularist approach' to better understand the critical value of the idea of civil society (Jensen, 2006, p. 54).

CSOs have over the years been described as monitoring agents, advocates, service providers, capacity builders, innovators of ideas, and peace builders. They consequently have a significant responsibility in nurturing the society's awareness, and this can ultimately encourage vital policy adjustments. In addition, CSOs are also useful in crafting guiding principles and maintaining civility among the public (Botchway, 2018b; Najam, 1999).

Furthermore, since various CSOs consider their participation in the adoption and formulation of policy as an essential mandate to represent the concerns and views of the underprivileged, they are usually regarded as a means to 'outlining the different policy options and deciding' which option is the best and this responsibility 'gives them status as "democratic" actors' (Pollard \& Court, 2005, p. 15). In addition, though many governments view CSOs as legitimate and helpful partners, the situation may differ from place to place. Thus, in countries where CSO activities are suppressed, civic groups ought to adapt different approaches in responding to diverse situations and government policies and positions on particular issues (Pollard \& Court, 2005; Nilsen, Strømsnes, \& Schmidt, 2018).

In recent times, CSOs have become very important intermediaries that help in formulating government policies. This they do by influencing the policy formulation process. Thus, through their mediation activities, and serving as the primary agents for establishing policy shift, CSOs make these policies realities and eventually influence their implementation (Pollard \& Court, 2005).

Civil society also usually provides the relevant know-how to other organizations that are in charge of the policy implementation process. Thus, though some CSOs may not have a direct role to play in the implementation policies, they proffer some relevant information needed for the effective implementation of such policies. Consequently, most CSOs, particularly policy think tanks have in recent times developed into crucial bridges linking 'those with practical experience of implementation and those with responsibility for policymaking' (Pollard \& Court, 2005, p. 18). They therefore provide plain and unbiased clarifications for both policy makers and implementers and by so doing absorb a great deal of 'the heat' that would have otherwise characterize 'their discussions.' Consequently, the 'technical expertise' of CSOs, coupled with their political neutrality usually allows for the introduction of 'more evidence into the public consultation process' (Pollard \& Court, 2005, p. 18).

Civil society is not NGO. Though NGOs may form part of the larger umbrella of civil society and some CSOs may qualify to be called NGOs, the two concepts are not necessarily interchangeable. Perhaps a better understanding of these two concepts may help in reducing the seemingly contradictory and overladen burden that has characterized CSOs over the years.

Studies have shown that the prevalence of ethnic segmentation within civil society eventually leads to the existence of weak networks and social capital that fosters generalized reciprocity across ethnic groups. Moreover, the lack of knowledge about the working environment, political process, as well as organizational structure and domestic politics affect the effectiveness of CSOs (Kröger, 2018b; Botchway, 2018b; Giersdorf \& Croissant, 2011). Furthermore, while CSOs and their activities remain imperative, they find themselves overshadowed today by state actors due to a host of reasons as identified earlier (Clark, 2011).

Evidence also exist to show that aside providing much needed services for the society, CSOs also usually operate as the nucleus for the collection and distribution of goods to other organizations that offer direct public welfare services (Simiti, 2017; Mercer \& Green, 2013). Consequently, this role of mediation permits civic groups that lack adequate funding to be active in the field of social welfare (Simiti, 2017). In addition, CSOs have in recent times been regarded by most donors and governments, as well as International Financial Institutions as 
conventional constituents in the quest for good governance, especially in developing states (Abrahamsen, 2001; Mercer, 2003).

Indeed CSOs have no inherent predetermined essential qualities and as such just like the state, and any other institution, they are liable to the influence of corrupt and undemocratic practices (Gibbon \& Bangura, 1992). Thus, in most developing countries, an augmented funding for some CSOs may perhaps tend to undercut efforts at promoting a more participatory and representative CSO in the long run (Mercer, 2002).

Finally, whereas the activities of CSOs in the developed world usually focuses on specific-issue based programs such as gender equality and equal rights, as well as climate change and humanitarian issues, those in the developing world are usually engaged in democracy-related issues and poverty alleviation. It must however be noted that CSOs activities in these two environments are not mutually exclusive though a clear pattern exist as can be seen from the extant literature discussed above.

\section{References}

Abrahamsen, R. (2001). Disciplining democracy: development discourse and good governance in Africa. London: Zed.

Beck, U. (1999). World Risk Society. Cambridge: Polity Press.

Berman, S. (1997). Civil Society and the Collapse of the Weimar Republic. World Politics, 49(3), 401-429. https://doi.org/10.1353/wp.1997.0008

Bernhard, M., Tzelgov, E., Jung, D.-J., Coppedge, M., \& Lindberg, S. I. (2015). The Varieties of Democracy Core Civil Society Index. Gothenburg: The Varieties of Democracy Institute.

Botchway, T. P. (2018b). Civil society and the consolidation of democracy in Ghana's fourth republic. Cogent Social Sciences, 4, 1452840. https://doi.org/10.1080/23311886.2018.1452840

Botchway, T. P. (2018a). Ghana: A Consolidated Democracy? Asian Research Journal of Arts \& Social Sciences, 5(4), 1-13. https://doi.org/10.9734/ARJASS/2018/39713

Bratton, M. (1994). Civil Society and Political Transition in Africa. IDR Reports, Volume 11.

Carothers, T. (1999). Civil Society. Foreign Policy, 18-29. https://doi.org/10.2307/1149558

Chaney, P. (2016). Gendered Political Space: Civil Society, Contingency theory, and the Substantive Representation of Women. Journal of Civil Society, 198-223. https://doi.org/10.1080/17448689.2016.1178964

Clark, J. (2011). Civil Society in the Age of Crisis. Journal of Civil Society, 7(3), 241-263. https://doi.org/10.1080/17448689.2011.604986

Cohen, J. L., \& Arato, A. (1993). Civil Society and Political Theory. Cambridge: M.A.: M.I.T. Press.

Cohen, J. L., \& Arato, A. (1994). Civil Society and Political Theory. Cambridge, MA: MIT Press.

Cohen, J., \& Rogers, J. (1995). Associations and Democracy. London: Verso.

Cox, R. W. (1999). Civil Society at the turn of the millennium: prospects for an alternative world order. Review of International Relations, 25, 3-28.

Diamond, L. (1997). Civil Society and the Development of Democracy. Estudio/Working Paper /101, 1-72.

Diamond, L. (1994). Rethinking Civil Society: Towards Democratic Consolidation. Journal of Democracy, 5(3), 4-17. https://doi.org/10.1353/jod.1994.0041

Ferguson, A. (1767). An Essay on the History of Civil Society (5 ed.). London: T. CADELL.

Fung, A. (2003). Associations and Democracy: Between Theories, Hopes, and Realities. Annual Review of Sociology, 29, 515-539. https://doi.org/10.1146/annurev.soc.29.010202.100134

Fung, A., \& Wright, O. E. (2003). Deepening Democracy: Institutional Innovations in Empowered Participatory Governance. London: Verso.

Gibbon, P., \& Bangura, Y. (1992). Adjustment, authoritarianism and democracy: an introduction to some conceptual and empirical issues. In P. Gibbon, Y. Bangura, \& A. Ofstad (Eds.), Authoritarianism, democracy and adjustment: the politics of economic reform in Africa (pp. 7-38). Uppsala: Nordiska Afrikainstitutet.

Giersdorf, S., \& Croissant, A. (2011). Civil Society and Competitive Authoritarianism in Malaysia. Journal of 
Civil Society, 7(1), 1-21. https://doi.org/10.1080/17448689.2011.553401

Gyimah-Boadi, E. (1996). Civil Society in Africa. Journal of Democracy, 7(2), 118-132. https://doi.org/10.1353/jod.1996.0025

Habermas, J. (1996). Between Facts and Norms: Contributions to a Discourse Theory of Law and Democracy. Cambridge: MIT Press. https://doi.org/10.7551/mitpress/1564.001.0001

Habermas, J. (2001). Why Europe needs a constitution. New Left Review, 11, 5-26.

Hirst, P. (1994). Associative Democracy: New Forms of Economic and Social Governance. Amherst: University of Massachusettes Press.

Hutchful, E. (1995). The Civil Society Debate in Africa. International Journal, 54-77. https://doi.org/10.2307/40203751

Jensen, M. N. (2006). Concepts and conceptions of civil society. Journal of Civil Society, 2(1), 39-56. https://doi.org/10.1080/17448680600730934

Kröger, S. (2018a). Strategic or Principled? The Engagement of Civil Society Organizations with the EU. Journal of Civil Society, 14(1), 41-57. https://doi.org/10.1080/17448689.2017.1401764

Kröger, S. (2018b). The Europeanisation of interest groups: beyond access, fit and resources. Journal of European Integration, 17-31. https://doi.org/10.1080/07036337.2017.1345899

Lewis, D. (2013). Civil Society and the Authoritarian State: Cooperation, Contestation and Discourse. Journal of Civil Society, 9(3), 325-340. https://doi.org/10.1080/17448689.2013.818767

Martin, S. J., \& Andrée, P. (2017). Putting Food Sovereignty to Work: Civil Society Society Governmentalities and Canada's People's Food Policy Project (2008-2011). Journal of Civil Society, 13(4), 374-391. https://doi.org/10.1080/17448689.2017.1355034

Masterson, G. (2007). Defining Civil Society In The Context of the African Peer Review Mechanism. In Matlosa, \& Chiroro (Eds.), Conflict, Democracy and Development. EISA.

Mercer, C. (2002). NGOs, civil society and democratization: a critical review of the literature. Progress in Development Studies, 2(1), 5-22. https://doi.org/10.1191/1464993402ps027ra

Mercer, C. (2003). Performing partnership: civil society and the illusions of good governance in Tanzania. Political Geography, 22, 741-763. https://doi.org/10.1016/S0962-6298(03)00103-3

Mercer, C., \& Green, M. (2013). Making civil society work: Contracting, cosmopolitanism and community development in Tanzania. Geoforum, 45, 106-115. https://doi.org/10.1016/j.geoforum.2012.10.008

Morley, H. (1884). John Locke's Two Treatises on Civil Government. London: George Routledge and Sons.

Najam, A. (1999). Citizen organizations as policy entrepreneurs. In D. Lewis (Ed.), International perspectives in voluntary action: reshaping the third sector. London: Earthscan.

Nilsen, H. R., Strømsnes, K., \& Schmidt, U. (2018). A Broad Alliance of Civil Society Organizations on Climate Change Mitigation: Political Strength or Legitimizing Support? Journal of Civil Society, 20-40. https://doi.org/10.1080/17448689.2017.1399596

Pollard, A., \& Court, J. (2005). How Civil Society Organisations Use Evidence to Influence Policy Processes: A literature review. London: Overseas Development Institute.

Putnam, R. (1993). Making Democracy Work: Civic Tradition in Modern Italy. Princeton: Princeton University Press.

Riley, D. J. (2010). The Civic Foundations of Fascism in Europe: Italy, Spain, and Romania 1870-1945. Baltimore: Johns Hopkins University Press.

Schedler, A. (2009). The new institutionalism in the study of authoritarian regimes. Totalitarianism and Democracy, 6(2), 327-344. https://doi.org/10.13109/tode.2009.6.2.323

Simiti, M. (2017). Civil Society and the Economy: Greek Civil Society during the Economic Crisis. Journal of Civil Society, 13(4), 357-373. https://doi.org/10.1080/17448689.2017.1355033

Walzer, M. (1991). The Idea of Civil Society. Dissent, 293-304.

Warren, M. E. (2001). Democracy and Association. New Jersey: Princeton University Press.

Warren, M. E. (1999). Civil Society and Good Governance. Washington: Department of Government, 
Georgetown University.

Whitfield, L. (2002). Civil Society as Idea and Civil Society as Process: The Case of Ghana. London: Queen Elizabeth House \& St Antony's College.

Woll, C., \& Jacqot, S. (2010). Using Europe: Strategic action in multi-level politics. Comparative European Politics, 8(1), 110-126. https://doi.org/10.1057/cep.2010.7

\section{Copyrights}

Copyright for this article is retained by the author(s), with first publication rights granted to the journal.

This is an open-access article distributed under the terms and conditions of the Creative Commons Attribution license (http://creativecommons.org/licenses/by/4.0/). 